\title{
ANALISIS VARIASI TEMPERATURE LINGKUNGAN TERHADAP KEAUSAN KAMPAS REM
}

\author{
Reynaldi Satria Gumilang, Darmanto, Agung Nugroho \\ Jurusan Teknik Mesin , Fakultas Teknik, Universitas Wahid Hasyim \\ Jl. Menoreh Tengah X/22. Sampangan, Semarang 50236 \\ Email : reynaldisg12@gmail.com
}

\begin{abstract}
Abstrak
Kampas rem adalah salah satu komponen kendaraan bermotor yang berfungsi untuk memperlambat atau menghentikan laju kendaraan bermotor. Dalam konsep pengereman hal yang tidak dapat dihindarkan adalah sebuah keausan. Keausan terjadi apabila dua buah benda yang saling menekan dan saling bergesekan. Dalam penelitian ini, dilakukan untuk mengetahui pengaruh temperatur Lingkungan terhadap volume keausan dan laju keausan kampas rem dengan menggunakan alat uji keausan kampas rem dengan variasi suhu 30, 35, 40, 45 dan $50{ }^{\circ} \mathrm{C}$ dengan beban pengereman $2 \mathrm{Kg}$. Durasi waktu pengujian yaitu 50 menit dilakukan pengambilan data per 10 menit. Hasil penelitian ini volume keausan tertinggi yaitu pada suhu $30{ }^{\circ} \mathrm{C}$ sisi kampas A 102,69 mm3 dan sisi kampas B 81,42 mm3 dan keausan volume keausan terkecil pada suhu $50{ }^{\circ} \mathrm{C}$ sisi kampas A 60,148 mm3 dan sisi kampas $B$ 46,211 mm3, Dan nilai laju keausan terbesar pada suhu $30{ }^{\circ} \mathrm{C}$ sisi kampas A 1,12E-07

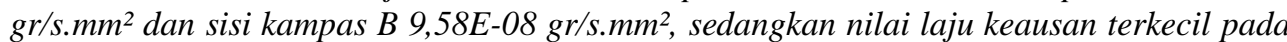
suhu $50{ }^{\circ} \mathrm{C}$ sisi kampas A 4,85E-08 gr/s. $\mathrm{mm}^{2}$ dan sisi kampas B 4,59E-08 gr/s. $\mathrm{mm}^{2}$.
\end{abstract}

Kata kunci: Kampas Rem, Temperatur Lingkungan, Keausan.

\section{PENDAHULUAN}

Keausan (wear) adalah hilangnya material dari permukaan benda padat sebagai akibat dari adanya gerakan mekanik. Keausan umunya dianalogikan sebagai hilangnya materi akibat interaksi mekanik dua permukaan yang bergerak sliding dan dibebani. Fenomena Ini merupakan hal yang normal terjadi jika dua permukaan benda saling bergesekan, maka akan ada keausan atau perpindahan materi yang terjadi antara dua benda yang bergesekan (Blau, 1997).

Kampas rem merupakan salah satu komponen dalam system pengereman sepeda motor yang bekerja dengan prinsip gesekan. Terdapat beberapa faktor yang mempengaruhi keausan pada benda yang mengalami gesekan misalnya material disk dan brake pad, Behavior pengemudi, dan keadaan lingkungan saat berkendara (Lancaster dkk., 1997). Tujuan penelitian ini untuk mengetahui pengaruh temperature lingkungan pengereman terhadap volume, laju dan kadar keausan pada kampas rem

\section{METODOLOGI}

Alat uji keausan kampas rem yang digunakann dalam penelitian ini ditunjukkan pada Gambar 1. Pengujian menggunakan kampas rem KR3-404 dengan durasi pengujian keausan selama 50 menit. Temperature lingkungan dimodelkan dengan pemanas buatan. Suhu diatur pada $30{ }^{\circ} \mathrm{C}, 35^{\circ} \mathrm{C}, 40{ }^{\circ} \mathrm{C}, 45^{\circ} \mathrm{C}$ dan $50^{\circ} \mathrm{C}$.

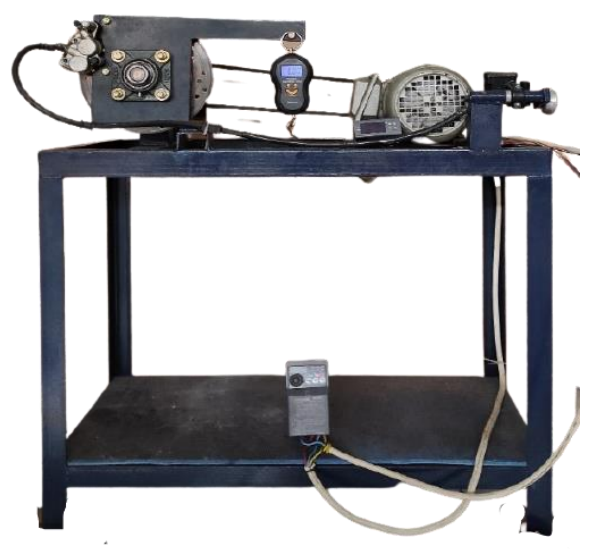

Gambar 1. Alat uji keausan kampas rem

Pembebanan $2 \mathrm{Kg}$ dengan waktu pengereman 50 menit, dan dilakukan penimbangan setiap 10 menit. Data hasil penelitian yang telah dilakukan, diperoleh data yang menunjukkan pengaruh variasi Temperature Lingkungan terhadap volume keausan dan laju keausan. 

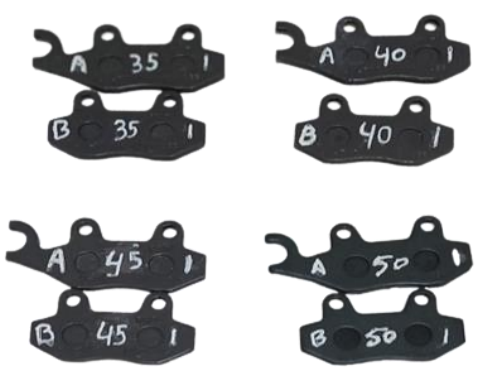

Gambar 2. Kampas rem

Langkah selanjutnya adalah menghitung Volume keausan dengan menggunakan rumus (Sukamto, 2013)

$V=\frac{m 1-m 2}{\rho}$

Laju keausan pada kampas rem dapat dihitung dengan rumus

$N=\frac{m 1-m 2}{t . A}$.

Dimana:

V : Volume keausan (mm3)

m1 : berat awal (gram)

m2 : berat setelah pengujian (gram)

$\rho \quad$ : massa jenis material(gram $/ \mathrm{mm} 3$ )

$\mathrm{N} \quad$ : Nilai laju keausan

(gram/detik.mm²)

$\mathrm{T} \quad$ : Waktu pengausan (detik)

A : Luas penampang $\left(\mathrm{mm}^{2}\right)$

Tekstur kampas diamati menggunakan pendekatan foto makro. Sebelum dan sesudah melakukan pengujian spesimen dilakukan foto makro untuk mengetahui bentuk awal dari spesimen yang akan diuji dan bentuk kekasaran setelah diuji. Selain itu untuk mengetahui kekasaran kampas rem dilakukan uji kekasaran permukaan sebelum dan sesudah pengujian.

\section{HASIL DAN PEMBAHASAN}

Dari gambar 3 menunjukkan bahwa volume keausan terbesar terjadi pada suhu $30{ }^{\circ} \mathrm{C}$ kampas rem Sisi A dengan nilai Volume Keausan 102,69 mm3 Dan kampas rem sisi B yaitu 81,42 $\mathrm{mm} 3$, hal ini dikarenakan suhu lingkungan $30{ }^{\circ} \mathrm{C}$ terhadap pengereman cukup dingin dibandingkan dengan variasi suhu $35,40,45$ dan $50{ }^{\circ} \mathrm{C}$ sehingga kampas rem mengalami gesekan yang semakin besar, begitu pula sebaliknya.
Sehingga dapat disimpulkan semakin dingin suhu lingkungan maka tingkat keausannya pada kampas semakin tinggi dan berlaku sebaliknya.

Tabel 1. volume keausan kampas rem

\begin{tabular}{|c|c|c|c|c|c|}
\hline \multirow{2}{*}{$\begin{array}{l}\text { Waktu } \\
\text { (s) }\end{array}$} & \multirow{2}{*}{$\begin{array}{l}\text { Jarak } \\
(\mathbf{k m})\end{array}$} & $\begin{array}{l}\text { Volume } \\
\left(\mathrm{mm}^{3}\right)\end{array}$ & Keausan & $\begin{array}{l}\text { Volume } \\
\left(\mathrm{mm}^{3}\right)\end{array}$ & Keausan \\
\hline & & $\begin{array}{c}\text { Sisi A } \\
30\end{array}$ & $\begin{array}{c}\text { Sisi B } \\
30 \\
\end{array}$ & $\begin{array}{c}\text { Sisi A } \\
35\end{array}$ & $\begin{array}{c}\text { Sisi B } \\
35 \\
\end{array}$ \\
\hline 600 & 7,613 & 31,174 & 26,773 & 29,34 & 28,607 \\
\hline 1200 & 15,226 & 48,412 & 42,911 & 42,177 & 38,509 \\
\hline 1800 & 22,839 & 69,317 & 56,481 & 52,08 & 47,678 \\
\hline 2400 & 30,452 & 86,555 & 69,317 & 62,716 & 56,114 \\
\hline 3000 & 38,065 & 102,693 & 81,42 & 71,518 & 66,383 \\
\hline
\end{tabular}

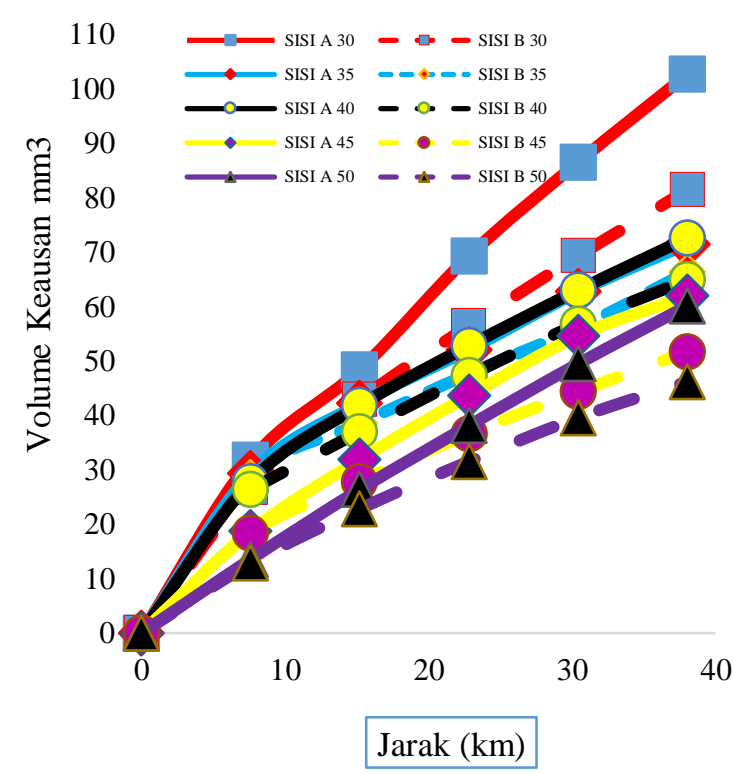

\section{Gambar 3. Perbandingan Volume Keausan}

Variasi temperature lingkungan 30, $35,40,45$ dan $50{ }^{\circ} \mathrm{C}$. Dari tabel 2 bisa dibuat menjadi sebuah grafik perbandingan laju keausan pada kampas rem variasi suhu $30,35,40,45$ dan $50{ }^{\circ} \mathrm{C}$. Dari gambar 4 menunjukkan bahwa laju keausan cenderung mengalami penurunan karena perubahan kekasaran permukaan material yang terjadi pada material kampas tersebut sehingga mengakibatkan material kampas menjadi lebih licin, dari grafik diatas laju keausan paling besar terjadi pada suhu $30^{\circ} \mathrm{C}$ kampas sisi A dan laju keausan paling rendah pada 
suhu $50{ }^{\circ} \mathrm{C}$ kampas sisi B dikarenakan semakin panas suhu lingkungan maka semakin rendah gaya gesek antara kampas dengan disc/selip. Volume Keausan terbesar terdapat pada kampas sisi A $30{ }^{\circ} \mathrm{C}$ karena semakin rendah temperatur lingkungan volume keausannya semakin besar, sebaliknya semakin tinggi temperaturnya maka volume keausannya semakin kecil.

Tabel 2. Keausan tiap sisi

\begin{tabular}{|c|c|c|c|c|c|}
\hline \multirow{2}{*}{$\begin{array}{c}\text { Waktu } \\
\text { (s) }\end{array}$} & \multirow{2}{*}{$\begin{array}{c}\text { Jarak } \\
(\mathbf{k m})\end{array}$} & \multicolumn{2}{|c|}{$\begin{array}{c}\text { Laju Keausan } \\
\left(\mathrm{gr} / \mathrm{s} . \mathrm{mm}^{2}\right)\end{array}$} & \multicolumn{2}{|c|}{$\begin{array}{c}\text { Laju Keausan } \\
(\text { gr/s.mm²) }\end{array}$} \\
\hline & & $\begin{array}{c}\text { Sisi A } \\
\mathbf{3 0}\end{array}$ & $\begin{array}{c}\text { Sisi B } \\
\mathbf{3 0}\end{array}$ & $\begin{array}{c}\text { Sisi A } \\
35\end{array}$ & $\begin{array}{c}\text { Sisi B } \\
35 \\
\end{array}$ \\
\hline 0 & 0 & 0 & 0 & 0 & 0 \\
\hline 600 & 7,613 & $\begin{array}{l}1,12 \mathrm{E}- \\
07 \\
8,66 \mathrm{E}-\end{array}$ & $\begin{array}{l}9,58 \mathrm{E}- \\
08 \\
7,67 \mathrm{E}-\end{array}$ & $\begin{array}{l}1,05 \mathrm{E}- \\
07 \\
7,54 \mathrm{E}-\end{array}$ & $\begin{array}{l}1,02 \mathrm{E}- \\
07 \\
6,89 \mathrm{E}-\end{array}$ \\
\hline 1200 & 15,23 & $\begin{array}{l}08 \\
8,27 \mathrm{E}-\end{array}$ & $\begin{array}{l}08 \\
6,73 \mathrm{E}-\end{array}$ & $\begin{array}{l}08 \\
6,21 \mathrm{E}-\end{array}$ & $\begin{array}{l}08 \\
5,69 \mathrm{E}-\end{array}$ \\
\hline 1800 & 22,84 & 08 & 08 & 08 & 08 \\
\hline 2400 & 30,45 & $\begin{array}{l}7,74 \mathrm{E}- \\
08\end{array}$ & $6,2 \mathrm{E}-08$ & $\begin{array}{l}5,61 \mathrm{E}- \\
08\end{array}$ & $\begin{array}{l}5,02 \mathrm{E}- \\
08\end{array}$ \\
\hline 3000 & 38,07 & $\begin{array}{l}7,35 \mathrm{E}- \\
08\end{array}$ & $\begin{array}{l}5,83 \mathrm{E}- \\
08\end{array}$ & $\begin{array}{l}5,12 \mathrm{E}- \\
08\end{array}$ & $\begin{array}{l}4,75 \mathrm{E}- \\
08\end{array}$ \\
\hline
\end{tabular}

Tabel 3. Keausan tiap sisi

\begin{tabular}{cccccc}
\hline $\mathbf{A} 4 \mathbf{4 0}$ & $\mathbf{B} \mathbf{4 0}$ & $\mathbf{A ~ 4 5}$ & B 45 & A 50 & B 50 \\
\hline 0 & 0 & 0 & 0 & 0 & 0 \\
$9,97 \mathrm{E}-08$ & $9,45 \mathrm{E}-08$ & $6,69 \mathrm{E}-08$ & $6,56 \mathrm{E}-08$ & $4,85 \mathrm{E}-08$ & $4,59 \mathrm{E}-08$ \\
$7,48 \mathrm{E}-08$ & $6,63 \mathrm{E}-08$ & $5,71 \mathrm{E}-08$ & $4,99 \mathrm{E}-08$ & $4,72 \mathrm{E}-08$ & $4,00 \mathrm{E}-08$ \\
$6,30 \mathrm{E}-08$ & $5,64 \mathrm{E}-08$ & $5,20 \mathrm{E}-08$ & $4,37 \mathrm{E}-08$ & $4,55 \mathrm{E}-08$ & $3,76 \mathrm{E}-08$ \\
$5,64 \mathrm{E}-08$ & $5,08 \mathrm{E}-08$ & $4,89 \mathrm{E}-08$ & $3,97 \mathrm{E}-08$ & $4,43 \mathrm{E}-08$ & $3,54 \mathrm{E}-08$ \\
$5,20 \mathrm{E}-08$ & $4,64 \mathrm{E}-08$ & $4,43 \mathrm{E}-08$ & $3,70 \mathrm{E}-08$ & $4,30 \mathrm{E}-08$ & $3,31 \mathrm{E}-08$ \\
\hline
\end{tabular}

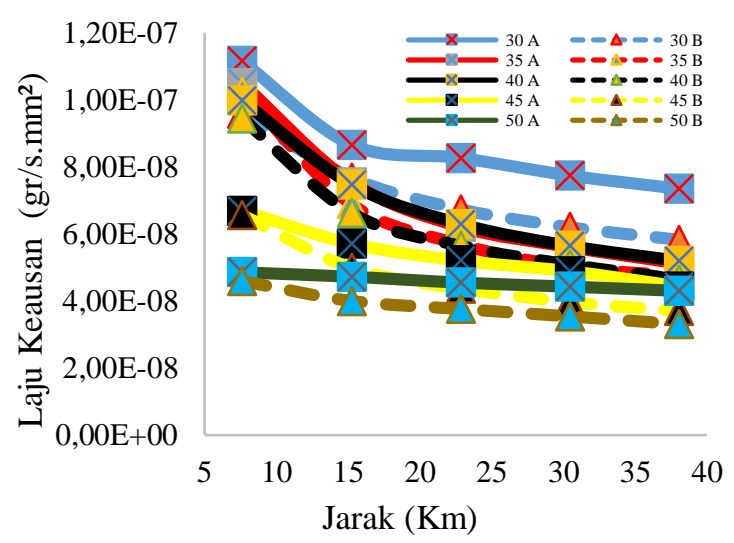

Gambar 4. Perbandingan laju Keausan
Laju keausan terbesar terdapat pada kampas sisi A $30{ }^{\circ} \mathrm{C}$ karena semakin rendah temperatur lingkungan maka semakin tinggi laju keausannya, sebaliknya semakin tinggi temperatur lingkungannya maka semakin rendah laju keausannya.

\section{DAFTAR PUSTAKA}

Blau, P. J. (1997). Fifty years of research on the wear of metals. Tribology International.

https://www.sciencedirect.com/scien ce/article/pii/S0301679X9600062X

Lancaster, J. G., Dowson, D., Isaac, G. H., \& Fisher, J. (1997). The wear of ultrahigh molecular weight polyethylene sliding on metallic and ceramic counterfaces representative of current femoral surfaces in joint replacement. Proceedings of the Institution of Mechanical Engineers, Part $\mathrm{H}$ : Journal of Engineering in Medicine, 211(1), $17-24$. https://doi.org/10.1243/09544119715 34647

Sukamto, B. A. J. (2013). Analisis Perpindahan Panas Kampas Rem Pada Sepeda Motor. In Teknik Mesin Universitas Janabadra, Yogyakarta.

PENUTUP

Kesimpulan 